\title{
Acyclic Diterpene Glycosides, Capsianosides C, D, E, F and III, from the Fruits of Hot Red Pepper Capsicum annuum L. Used in Kimchi and Their Revised Structures
}

\author{
Jong-Hyun Lee, Naoko KiYota, Tsuyoshi Ikeda, and Toshihiro NoharA* \\ Faculty of Medical and Pharmaceutical Sciences, Kumamoto University; 5-1 Oe-Honmachi, Kumamoto 862-0973, Japan. \\ Received February 7, 2007; accepted May 30, 2007; published online June 5, 2007
}

Acyclic diterpene glycosides, named capsianosides I', II, II (1), C (2), D (3), E (4) and F (5), have been isolated from the dried hot red pepper fruits of Capsicum annuum L. used in Kimchi. The structures of these compounds have been revised in the sugar connectivities by 1D- and 2D-NMR spectroscopic and chemical methods.

Key words hot red pepper; Capsicum annuum; Kimchi; capsianoside; acyclic diterpene glycoside; Solanaceae

Kimchi, a fermented Chinese cabbage product, has been prepared and consumed in Korea traditionally. Now its consumption is expanding worldwide owing to various functional properties such as anti-carcinogenic and anti-oxidative activities. ${ }^{1)}$ Kimchi is made of Chinese cabbage, with different spices, garlic, ginger and hot red pepper. ${ }^{2)}$ The Capsicum species is a very important plant used as vegetables, spices and external medicine, and capsaicinoids are the group of compounds responsible for the 'heat' sensation. These metabolites are also used as pest repellants in agriculture, and there is interest their synergistic use with organophosphate insecticides. ${ }^{3)}$ Capsaicin, a prototypical capsaicinoid, is used to mitigate neurogenic pain; several products applied as creams and gels (e.g. Axsain and Zostrix) have appeared on the market as topical analgesics, but irritance severely limits the pharmacological use of capsaicinoid. ${ }^{4)}$ Peppers are also a good source of vitamins A, C, and E, which are present in high concentration in various pepper types. ${ }^{5}$ Total flavonoid and phenolic components are important dietary antioxidants. ${ }^{6}$ Although carotenoids, lipids and capsaicins have been studied in depth, there are few reports on the highly polar components of the Capsicum species. Meanwhile, a novel acyclic diterpene glycoside, capsianoside A, was obtained from the part of the polar ingredients in the fresh fruits of Capsicum annuum L. var. fasciculatum IRISH. ${ }^{7)}$ Also, we isolated novel acyclic diterpene glycosides, capsianosides $\mathrm{A}-\mathrm{H}$ and $\mathrm{I}-\mathrm{VI}, \mathrm{VIII}-\mathrm{X}, \mathrm{XIII}, \mathrm{XV}$ and XVI, from Capsicum plants in the previous researches. ${ }^{8-10)}$ In this study, we have examined the chemical composition of the water-soluble fraction of dried hot red pepper fruits $C$. annuum L. used in Kimchi, and here we report the structure characterization of seven compounds, five of which $(\mathbf{1}-\mathbf{5})$ have been revised in the structures of the sugar connectivities.

Capsianoside III (1) was obtained as an amorphous powder showing $[\alpha]_{\mathrm{D}}-28.6^{\circ}(\mathrm{MeOH})$. It gave a molecular formula $\mathrm{C}_{50} \mathrm{H}_{84} \mathrm{O}_{26} \mathrm{Na}$ at $m / z 1123.5127$ by HR-ESI-MS. The ${ }^{1} \mathrm{H}-\mathrm{NMR}$ spectrum of $\mathbf{1}$ showed the presence of four methyl groups at $\delta 1.39(3 \mathrm{H}, \mathrm{s}), 1.61(6 \mathrm{H}, \mathrm{s})$ and $1.79(3 \mathrm{H}, \mathrm{s})$, three olefinic protons at $\delta 5.22(1 \mathrm{H}$, brd $), 5.23(1 \mathrm{H}$, br d) and 6.13 $(1 \mathrm{H}, \mathrm{dd}, J=11.0,18.3 \mathrm{~Hz})$ arising from a mono-substituted double bond, three olefinic protons at $\delta 5.13(2 \mathrm{H}, \mathrm{m})$ and $5.39(1 \mathrm{H}, \mathrm{t})$ adjacent to methylene group and seven methylene groups at $\delta 1.60(2 \mathrm{H}, \mathrm{m}), 1.95-2.20(10 \mathrm{H}, \mathrm{m}), 4.21$ $(1 \mathrm{H}, \mathrm{d}, J=11.6 \mathrm{~Hz})$ and $4.30(1 \mathrm{H}, \mathrm{d}, J=11.6 \mathrm{~Hz})$. Further- more, the ${ }^{13} \mathrm{C}$-NMR spectrum of $\mathbf{1}$ as listed in Table 1 showed total twenty carbon signals composed of three trisubstituted double bonds at $\delta$ 125.8, 126.0, 131.3, 132.5, 135.5 and 136.1, mono-substituted double bond at $\delta 116.0$ and 144.5, four methyl groups at $\delta 16.3(2 \times \mathrm{C}), 22.0$ and 23.4 and seven methylene groups at $\delta 23.6,27.3,27.7,40.8$, $40.9,43.1$ and 68.3. Since all the signals due to the aglycone moiety of capsianoside III (1) in the ${ }^{1} \mathrm{H}$ - and ${ }^{13} \mathrm{C}$-NMR spectra were identical with those of capsianoside III reported previously, ${ }^{8)}$ the configuration at C-3 was regarded as $S$, suggesting that the aglycone moiety is 17-hydroxy- $6 E, 10 E, 14 Z-(3 S)$ geranyl-linalool. Other sapogenols of capsianosides C (2), D (3), E (4) and F (5) were also coincident with that of $\mathbf{1}$. The ${ }^{1} \mathrm{H}-\mathrm{NMR}$ spectrum 1 showed the presence of $4 \mathrm{~mol}$ of hexosyl and $1 \mathrm{~mol}$ of deoxyhexosyl moieties based on the signals ascribable to five anomeric protons at $\delta 4.35(1 \mathrm{H}, \mathrm{d}$, $J=7.3 \mathrm{~Hz}), 4.47(1 \mathrm{H}, \mathrm{d}, J=7.9 \mathrm{~Hz}), 4.56(1 \mathrm{H}, \mathrm{d}, J=7.9 \mathrm{~Hz})$, $4.63(1 \mathrm{H}, \mathrm{d}, J=7.9 \mathrm{~Hz})$ and $4.75(1 \mathrm{H}, \mathrm{s})$. On the other hand,

Table 1. ${ }^{13} \mathrm{C}-\mathrm{NMR}(125 \mathrm{MHz})$ Spectroscopic Data for Compound $\mathbf{1}$ in $\mathrm{CD}_{3} \mathrm{OD}$

\begin{tabular}{|c|c|c|c|c|c|}
\hline Position & $\delta_{\mathrm{C}}$ & Position & $\delta_{\mathrm{C}}$ & Position & $\delta_{\mathrm{C}}$ \\
\hline Aglycone moiety & \multicolumn{4}{|c|}{ Sugar moiety } & \\
\hline 1 & 116.0 & Glc I & & Glc IV & \\
\hline 2 & 144.5 & 1 & 98.4 & 1 & 104.9 \\
\hline 3 & 82.1 & 2 & 83.3 & 2 & 75.9 \\
\hline 4 & 43.1 & 3 & 77.8 & 3 & 78.2 \\
\hline 5 & 23.6 & 4 & 71.4 & 4 & 71.7 \\
\hline 6 & 126.0 & 5 & 77.5 & 5 & 78.1 \\
\hline 7 & 135.5 & 6 & 62.9 & 6 & 62.8 \\
\hline 8 & 40.8 & & & & \\
\hline 9 & 27.7 & Glc II & & Rha & \\
\hline 10 & 125.8 & 1 & 105.9 & 1 & 102.1 \\
\hline 11 & 136.1 & 2 & 76.7 & 2 & 72.2 \\
\hline 12 & 40.9 & 3 & 78.3 & 3 & 72.5 \\
\hline 13 & 27.3 & 4 & 71.5 & 4 & 74.1 \\
\hline 14 & 131.3 & 5 & 78.1 & 5 & 69.8 \\
\hline 15 & 132.5 & 6 & 62.8 & 6 & 18.1 \\
\hline 16 & 22.0 & & & & \\
\hline 17 & 68.3 & Glc III & & & \\
\hline 18 & 16.3 & 1 & 101.2 & & \\
\hline 19 & 16.3 & 2 & 82.1 & & \\
\hline \multirow[t]{4}{*}{20} & 23.4 & 3 & 77.7 & & \\
\hline & & 4 & 71.6 & & \\
\hline & & 5 & 76.6 & & \\
\hline & & 6 & 67.7 & & \\
\hline
\end{tabular}




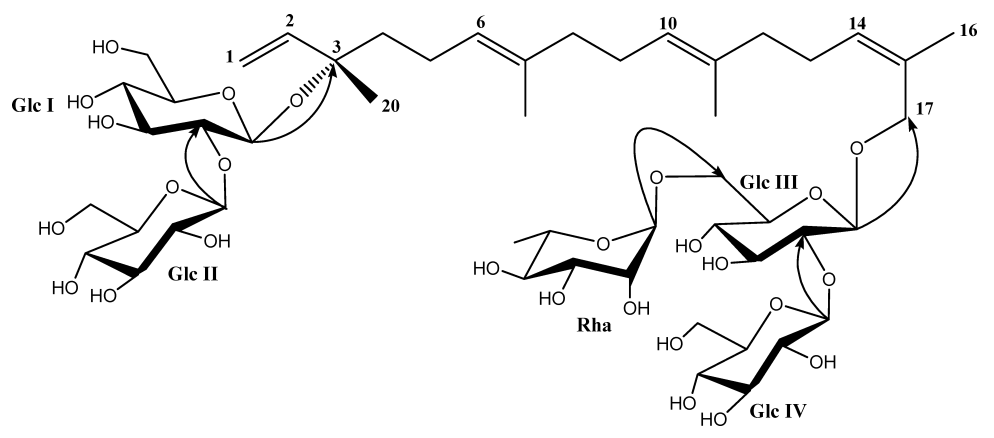

Fig. 1. Key HMBC of 1

the ${ }^{13} \mathrm{C}-\mathrm{NMR}$ spectrum also exhibited five anomeric carbon signals at $\delta 105.9,104.9,102.1,101.2$ and 98.4. Acid hydrolysis of 1 afforded glucose and rhamnose. The HMBC correlations as shown in Fig. 1 revealed the respective sugar connectivities: correlations between the signal at $\delta_{\mathrm{H}} 4.47$ $(1 \mathrm{H}, \mathrm{d}, J=7.9 \mathrm{~Hz})$ and the signal at $\delta_{\mathrm{C}} 82.1$ (aglycone C-3) indicating the Glc I H-1 to be linked to the C-3 of the aglycone; the signal at $\delta_{\mathrm{H}} 4.56(1 \mathrm{H}, \mathrm{d}, J=7.9 \mathrm{~Hz})$ and the signal at $\delta_{\mathrm{C}} 83.3$ (Glc I C-2) showing the Glc II H-1 to be linked to the C-2 of the Glc I; the signal at $\delta_{\mathrm{H}} 4.35(1 \mathrm{H}, \mathrm{d}, J=7.3 \mathrm{~Hz})$ and the signal at $\delta_{\mathrm{C}} 68.3$ (aglycone C-17) exhibiting the Glc III $\mathrm{H}-1$ to be linked to the $\mathrm{C}-17$ of the aglycone; the signal at $\delta_{\mathrm{H}} 4.63(1 \mathrm{H}, \mathrm{d}, J=7.9 \mathrm{~Hz})$ and the signal at $\delta_{\mathrm{C}} 82.1$ (Glc III $\mathrm{C}-2$ ) indicating the Glc IV $\mathrm{H}-1$ to be bound to the Glc III C2 ; the signal at $\delta_{\mathrm{H}} 4.75(1 \mathrm{H}, \mathrm{s})$ and the signal at $\delta_{\mathrm{C}} 67.7(\mathrm{Glc}$ III C-6) showing the Rha H-1 to be linked to the Glc III $\mathrm{C}-6$. The sugar structure at the 17-O-part, 17-O- $\beta$-D-glucopyranosyl- $(1 \rightarrow 2)-\beta$-D-glucopyranosyl- $(1 \rightarrow 6)-\alpha$-L-rhamnopyranoside, for 1 previously reported ${ }^{8)}$ should be revised. Therefore, the structure of 1 was determined to be 3-O$\beta$-D-glucopyranosyl-( $\rightarrow 2$ )- $\beta$-D-glucopyranosyl 17 -hydroxy$6 E, 10 E, 14 Z-(3 S)$-geranyllinalool $17-O-\beta$-D-glucopyranosyl$(1 \rightarrow 2)$ - $[\alpha$-L-rhamnopyranosyl- $(1 \rightarrow 6)]-\beta$-D-glucopyranoside.

Capsianoside $\mathrm{C}$ (2) was obtained as an amorphous powder showing $[\alpha]_{\mathrm{D}}-23.5^{\circ}(\mathrm{MeOH})$. The molecular formula was determined to be $\mathrm{C}_{82} \mathrm{H}_{134} \mathrm{O}_{38} \mathrm{Na}$ by HR-ESI-MS $(\mathrm{m} / \mathrm{z}$ 1749.8584). The ${ }^{1} \mathrm{H}$ - and ${ }^{13} \mathrm{C}-\mathrm{NMR}$ signals due to the sapogenol part indicated that the sapogenol part of $\mathbf{2}$ comprised a 17-hydroxy-6E,10E,14Z-(3S)-geranyllinalool and a $6 E, 10 E, 14 E$-13-hydroxy-(3S)-geranyllinalool-16-oic acid previously reported for dimeric ester compounds, capsianosides. ${ }^{8)}$ The ${ }^{1} \mathrm{H}-\mathrm{NMR}$ signals due to the sapogenol parts, were assigned as follows; eight methyl groups $[\delta 1.39(6 \mathrm{H}, \mathrm{s}$, $\left.\mathrm{H}_{3}-20,20^{\prime}\right), 1.61\left(9 \mathrm{H}, \mathrm{s}, \mathrm{H}_{3}-18^{\prime}, 19,19^{\prime}\right), 1.66\left(3 \mathrm{H}, \mathrm{s}, \mathrm{H}_{3}-\right.$ 18), $1.77\left(3 \mathrm{H}, \mathrm{s}, \mathrm{H}_{3}-16^{\prime}\right)$ and $\left.1.89\left(3 \mathrm{H}, \mathrm{s}, \mathrm{H}_{3}-17\right)\right]$, two monosubstituted double bonds $[\delta 5.22(2 \mathrm{H}, \mathrm{d}, J=11.6 \mathrm{~Hz}, \mathrm{H}-1 \mathrm{~b}$, $\left.1^{\prime} \mathrm{b}\right), 5.23\left(2 \mathrm{H}, \mathrm{d}, J=17.1 \mathrm{~Hz}, \mathrm{H}-1 \mathrm{a}, 1^{\prime} \mathrm{a}\right)$ and $6.12(2 \mathrm{H}, \mathrm{dd}$, $\left.\left.J=10.7,18.0 \mathrm{~Hz}, \mathrm{H}-2,2^{\prime}\right)\right]$, five olefinic protons $[\delta 5.12(3 \mathrm{H}$, $\left.\mathrm{m}, \mathrm{H}-6,6^{\prime}, 10^{\prime}\right), 5.21(1 \mathrm{H}, \mathrm{m}, \mathrm{H}-10)$ and $\left.5.40\left(1 \mathrm{H}, \mathrm{t}, \mathrm{H}-14^{\prime}\right)\right]$ and one olefinic proton $[\delta 6.71(1 \mathrm{H}, \mathrm{dd}, J=1.2,8.6 \mathrm{~Hz}, \mathrm{H}-$ 14)] coupled with an oxygenated methine proton $[\delta 4.53$ $(1 \mathrm{H}, \mathrm{m}, \mathrm{H}-13)]$, twelve methylene groups $[\delta 1.60(4 \mathrm{H}, \mathrm{m}, \mathrm{H}-$ $\left.4,4^{\prime}\right), 1.99-2.28(18 \mathrm{H}, \mathrm{m}), 4.33\left(1 \mathrm{H}, \mathrm{d}, J=11.6 \mathrm{~Hz}, \mathrm{H}-17^{\prime} \mathrm{a}\right)$ and $\left.4.12\left(1 \mathrm{H}, \mathrm{d}, J=11.6 \mathrm{~Hz}, \mathrm{H}-17^{\prime} \mathrm{b}\right)\right]$. Also, the ${ }^{13} \mathrm{C}-\mathrm{NMR}$ spectrum of 2 displayed eight methyl carbons at $\delta 13.1,16.3$ $(3 \times \mathrm{C}), 16.8,21.9,23.5(2 \times \mathrm{C})$, eleven methylene carbons at $\delta 43.1(2 \times \mathrm{C}), 23.6(2 \times \mathrm{C}), 40.5,27.7,47.9,40.8,27.8,40.9$, 27.3 , one methine carbon at $\delta 68.0$, two quarternary carbons at $\delta 82.1(2 \times \mathrm{C})$ with an oxygen function, sixteen double bond signals at $\delta 116.0(2 \times \mathrm{C}), 144.4(2 \times \mathrm{C}), 125.8,135.5$, $125.9(2 \times \mathrm{C}), 136.1,131.3,132.4,136.0,129.3,131.8$, $145.9,128.9$ and one methylene carbon at $\delta 67.7$. Moreover, a signal at $\delta 169.2$ was assigned to an ester carbonyl group. All the above carbon signals were also assigned by the aid of FGCOSY, HMQC and HMBC as in Table 2. The ${ }^{1} \mathrm{H}-\mathrm{NMR}$ signals originated from the sugar part of $\mathbf{2}$ showed seven anomeric proton signals $[\delta 4.21(1 \mathrm{H}, \mathrm{d}, J=7.9 \mathrm{~Hz}), 4.47$ $(2 \mathrm{H}, \mathrm{d}, J=7.3 \mathrm{~Hz}), 4.56(2 \mathrm{H}, \mathrm{d}, J=7.3 \mathrm{~Hz}), 4.81(1 \mathrm{H}, \mathrm{s})$ and $4.90(1 \mathrm{H}, \mathrm{s})]$. The ${ }^{13} \mathrm{C}-\mathrm{NMR}$ spectrum also showed seven anomeric carbon signals at $\delta 105.9(2 \times \mathrm{C}), 102.3,101.1$, 99.3 and $98.4(2 \times \mathrm{C})$ together with two methyl carbons $(\delta$ $18.0,18.2)$ arising from deoxyhexosyl moieties. Acid hydrolysis of 2 afforded glucose and rhamnose. The HMBC correlations revealed the respective sugar connectivities: correlations between the signal at $\delta_{\mathrm{H}} 4.47(2 \mathrm{H}, \mathrm{d}, J=7.3 \mathrm{~Hz})$ and the signal at $\delta_{\mathrm{C}} 82.1$ (aglycone $\mathrm{C}-3,3^{\prime}$ ) indicating the Glc I H-1 and Glc III H-1 to be linked to the $\mathrm{C}-3,3^{\prime}$ of the aglycone individually; the signal at $\delta_{\mathrm{H}} 4.56(2 \mathrm{H}, \mathrm{d}, J=7.3 \mathrm{~Hz})$ and the signal at $\delta_{\mathrm{C}} 83.3$ (C-2 of Glc I and Glc III) showing the Glc II $\mathrm{H}-1$ and Glc IV $\mathrm{H}-1$ to be linked to the C-2 of the Glc I and Glc III separately; the signal at $\delta_{\mathrm{H}} 4.21(1 \mathrm{H}, \mathrm{d}$, $J=7.9 \mathrm{~Hz}$ ) and the signal at $\delta_{\mathrm{C}} 67.7$ (aglycone C-17') exhibiting the Glc V H-1 to be linked to the C-17' of the aglycone; the signal at $\delta_{\mathrm{H}} 4.90(1 \mathrm{H}, \mathrm{s})$ and the signal at $\delta_{\mathrm{C}} 78.6$ (Glc V C-4) indicating the Rha I H-1 to be bound to the Glc V C-4; the signal at $\delta_{\mathrm{H}} 4.81(1 \mathrm{H}, \mathrm{s})$ and the signal at $\delta_{\mathrm{C}} 66.2$ (Glc V C-6) showing the Rha II H-1 to be linked to the Glc V C-6. The sugar structure previously reported ${ }^{8)}$ should be revised. Next, in order to determine the location of the ester bond, the ${ }^{1} \mathrm{H}-\mathrm{NMR}$ spectra of $\mathbf{2}$ and capsianoside $\mathrm{II}^{8)}$ were compared. The correlations were observed between an anomeric proton signal at $\delta 4.90$ and a carbon signal at $\delta$ 99.3 , between the signal $\delta 4.98$ of $\mathrm{H}-2$ in Rha I and a carbon signal at $\delta 75.0$, and between the signal $\delta 3.89$ of H-3 in Rha I and a carbon signal at $\delta 70.4$ in the HMQC. A proton signal at $\delta 4.98(1 \mathrm{H}, \mathrm{d}, J=3.1 \mathrm{~Hz})$ being geminal to the acyl group was observed in 2 . This signal correlated with the signals of anomeric proton $[\delta 4.90(1 \mathrm{H}, \mathrm{s})]$ and $\delta_{\mathrm{H}-3} 3.89$ of the rhamnosyl moiety in the TOCSY. Therefore, it was found that the hydroxyl group at $\mathrm{C}-2$ of the $\mathrm{Rha} \mathrm{I}$ is concerned with the ester bond. The absolute configurations at C-3 and C-3' in the aglycone part were suggested to be $3 S$ as in other capsianosides isolated, on the basis of optical rotation. Consequently, the structure of capsianoside $C$ (2) could be represented as $3^{\prime}-O$ - $\beta$-D-glucopyranosyl-( $\left.1 \rightarrow 2\right)-\beta$-D-glucopyranosyl $6^{\prime} E, 10^{\prime} E, 14^{\prime} Z-\left(3^{\prime} S\right)-17^{\prime}$-hydroxygeranyllinalool $17^{\prime}$ - 


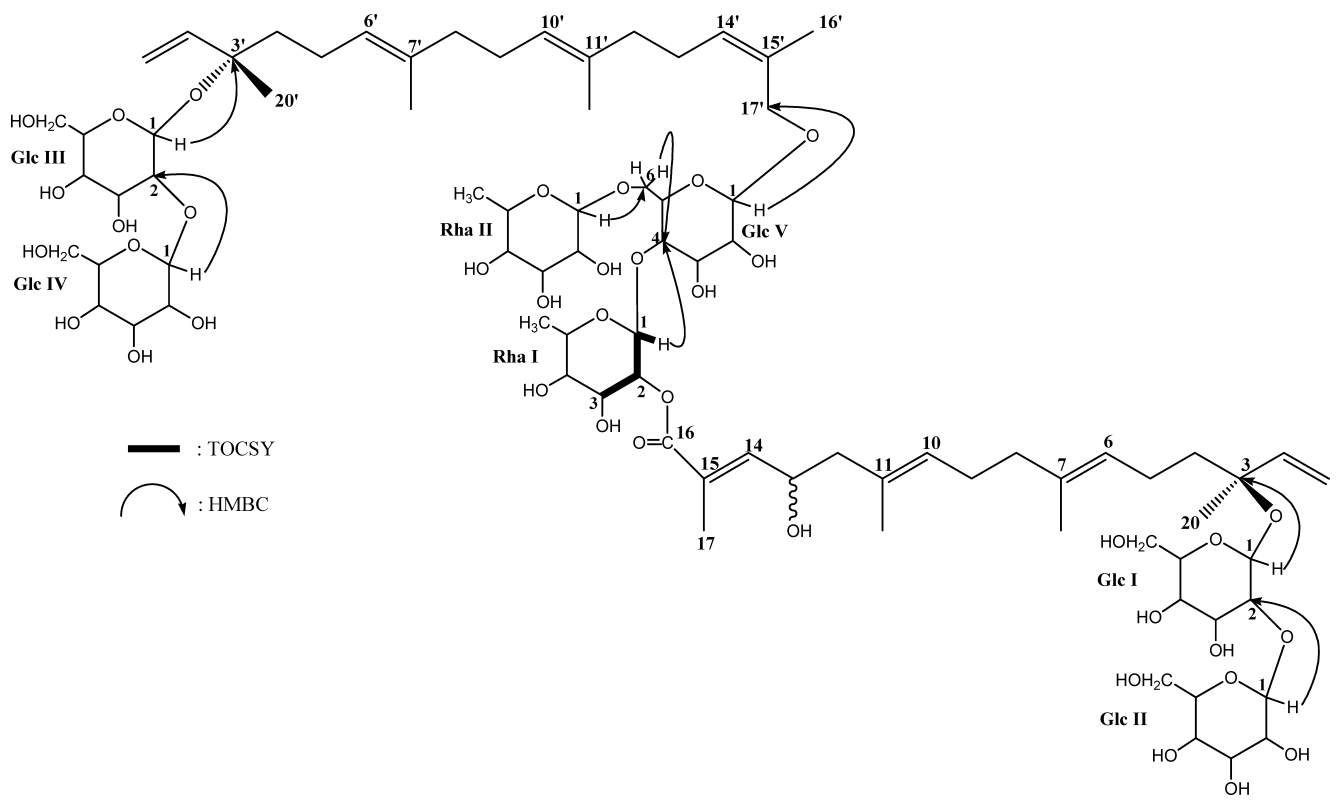

Fig. 2. Key HMBC and TOCSY of 2

$O$-[3- $O$ - $\beta$-D-glucopyranosyl-( $1 \rightarrow 2)$ - $\beta$-D-glucopyranosyl $6 E, 10 E, 14 E-(3 S)$-13-hydroxygeranyllinalool-16-oyl(16 $\rightarrow 2)]$ $\alpha$-L-rhamnopyranosyl-( $1 \rightarrow 4)$-[ $\alpha$-L-rhamnopyranosyl$(1 \rightarrow 6)]$ - $\beta$-D-glucopyranoside.

Capsianoside D (3), $[\alpha]_{\mathrm{D}}-27.4^{\circ}(\mathrm{MeOH})$, was obtained as an amorphous powder. The molecular formula was determined to be $\mathrm{C}_{82} \mathrm{H}_{134} \mathrm{O}_{38} \mathrm{Na}$ by HR-ESI-MS ( $m / z$ 1749.8251). Comparison of ${ }^{1} \mathrm{H}-,{ }^{13} \mathrm{C}-\mathrm{NMR}$ and mass spectrum data of 3 with those of $\mathbf{2}$ showed clearly their structural similarity. However, in the ${ }^{13} \mathrm{C}$-NMR spectrum of $\mathbf{3}$, the signals assignable to the Rha I appeared at $\delta 102.7,70.2,75.8,71.7,70.8$ and 18.2, suggesting that the hydroxyl group at C-3 of Rha I participated in the ester bonding. Moreover, in comparing the ${ }^{1} \mathrm{H}-\mathrm{NMR}$ spectrum of $\mathbf{3}$ with those of $\mathbf{2}$, the H-3 of the Rha I in 3 showed acylation shifts into $\delta 4.99(1 \mathrm{H}$, dd, $J=3.1$, $9.8 \mathrm{~Hz})$ together with the chemical shifts of $\delta 4.84(1 \mathrm{H}, \mathrm{s}$, Rha I H-1) and $\delta 4.03(1 \mathrm{H}, \mathrm{d}, J=3.1 \mathrm{~Hz}$, Rha I H-2). The signal of H-3 correlated with the signal at $\delta_{\mathrm{H}} 4.03(1 \mathrm{H}, \mathrm{d}$, $J=3.1 \mathrm{~Hz})$, and the anomeric proton signal $[\delta 4.84(1 \mathrm{H}, \mathrm{s})]$ correlated with the signal at $\delta_{\mathrm{H}} 4.03(1 \mathrm{H}, \mathrm{d}, J=3.1 \mathrm{~Hz})$ of the rhamnosyl moiety in the ${ }^{1} \mathrm{H}-{ }^{1} \mathrm{H}$ COSY. Consequently, it was found that the hydroxyl group at $\mathrm{C}-3$ of the Rha I is concerned with the ester bond. The structure of $\mathbf{3}$ was represented as $3^{\prime}-O-\beta$-D-glucopyranosyl- $(1 \rightarrow 2)-\beta$-D-glucopyranosyl $6^{\prime} E, 10^{\prime} E, 14^{\prime} Z-\left(3^{\prime} S\right)-17^{\prime}$-hydroxygeranyllinalool $17^{\prime}$ $O$-[3-O- $\beta$-D-glucopyranosyl- $(1 \rightarrow 2)-\beta$-D-glucopyranosyl $6 E, 10 E, 14 E-(3 S)$-13-hydroxygeranyllinalool-16-oyl(16 $\rightarrow 3)]-$ $\alpha$-L-rhamnopyranosyl-( $1 \rightarrow 4)$-[ $\alpha$-L-rhamnopyranosyl$(1 \rightarrow 6)]$ - $\beta$-D-glucopyranoside.

Capsianoside E (4) was obtained as an amorphous powder showing $[\alpha]_{\mathrm{D}}-33.4^{\circ}(\mathrm{MeOH})$. The molecular formula was determined to be $\mathrm{C}_{82} \mathrm{H}_{134} \mathrm{O}_{37} \mathrm{Na}$ by HR-ESI-MS $(\mathrm{m} / \mathrm{z}$ 1733.8426). Since compound 4 indicated the presence of an ester carbonyl group at $\delta 169.3$ in the ${ }^{13} \mathrm{C}$-NMR spectrum, 4 was regarded as an analogous compound such as $\mathbf{2}$ and $\mathbf{3}$. However, a signal $[\delta 4.53(1 \mathrm{H}, \mathrm{m})]$ assignable to $\mathrm{H}-13$, as well as appeared in $\mathbf{2}$ and $\mathbf{3}$, vanished, and a signal due to $\mathrm{H}$ 14 occurred at $\delta 6.85(1 \mathrm{H}, \mathrm{t}, \mathrm{H}-14)$ in 4 , thus suggesting the occurrence of the methylene group at $\mathrm{C}-13$ in 4 . This was also supported by the evidence of the ${ }^{13} \mathrm{C}$-NMR spectrum that the methine carbon due to $\mathrm{C}-13$ at $\delta 68.0$ in 2 appeared at $\delta 28.6$ as methylene carbon in 4 . The location of the ester bond was determined by HMQC and TOCSY. The signals due to the H-1, H-2 and H-3 of Rha I showed acylation shifts to appear at $\delta 4.90(1 \mathrm{H}, \mathrm{s}), 4.97(1 \mathrm{H}, \mathrm{d}, J=3.7 \mathrm{~Hz})$ and 3.88 $(1 \mathrm{H}, \mathrm{dd}, J=3.1,9.2 \mathrm{~Hz})$, which were coincident with those of 2 having an ester bond at $\mathrm{C}-2-\mathrm{OH}$ of the Rha I. The correlations were observed between an anomeric proton signal $(\delta$ 4.90) and a carbon signal at $\delta 99.4$, between the signal $\delta$ 4.97 of H-2 in Rha I and a carbon signal at $\delta 74.7$, and between the signal $\delta 3.88$ of $\mathrm{H}-3$ in Rha I and a carbon signal at $\delta 70.4$ in the HMQC. A proton signal at $\delta 4.97(1 \mathrm{H}, \mathrm{d}$, $J=3.7 \mathrm{~Hz}$ ) geminal to the acyl group was observed in 4 . This signal was correlated with the anomeric proton $[\delta 4.90(1 \mathrm{H}$, s)] and $\delta_{\mathrm{H}-3} 3.88$ of the rhamnosyl moiety in the TOCSY. So, it was found that the hydroxyl group at C-2 of the Rha $\mathrm{I}$ is concerned with the ester bond. Therefore, the structure of 4 was characterized as $3^{\prime}-O$ - $\beta$-D-glucopyranosyl- $(1 \rightarrow 2)-\beta$-Dglucopyranosyl $\quad 6^{\prime} E, 10^{\prime} E, 14^{\prime} Z-\left(3^{\prime} S\right)-17^{\prime}$-hydroxygeranyllinalool $17^{\prime}-O$-[3- $O$ - $\beta$-D-glucopyranosyl- $(1 \rightarrow 2)$ - $\beta$-D-glucopyranosyl $6 E, 10 E, 14 Z-(3 S)$-geranyllinalool-16-oyl $(16 \rightarrow 2)]-\alpha$ L-rhamnopyranosyl- $(1 \rightarrow 4)$ - $[\alpha$-L-rhamnopyranosyl- $(1 \rightarrow 6)]$ $\beta$-D-glucopyranoside.

Capsianoside $\mathrm{F}(\mathbf{5}),[\alpha]_{\mathrm{D}}-33.2^{\circ}(\mathrm{MeOH})$, was obtained as an amorphous powder. The molecular formula was determined to be $\mathrm{C}_{82} \mathrm{H}_{134} \mathrm{O}_{37} \mathrm{Na}$ by HR-ESI-MS ( $m / z$ 1733.8427). The ${ }^{1} \mathrm{H}-\mathrm{NMR}$ spectrum of $\mathbf{5}$ was very similar with that of $\mathbf{4}$, signals due to the H-1, H-2 and H-3 of the Rha I appeared at $\delta 4.84(1 \mathrm{H}, \mathrm{s}), 4.02(1 \mathrm{H}, \mathrm{d}, J=3.1 \mathrm{~Hz})$ and $4.98(1 \mathrm{H}, \mathrm{dd}$, $J=3.1,9.8 \mathrm{~Hz}$ ) as in the case of 3 . This fact indicated that the hydroxyl group at C-3 of the Rha I is concerned with the ester bond in 5. Besides, a proton signal at $\delta 4.98$ $(1 \mathrm{H}, \mathrm{dd}, J=3.1,9.8 \mathrm{~Hz})$ geminal to the acyl group was observed in 5. This signal was correlated with $\delta_{\mathrm{H}} 4.02(1 \mathrm{H}$, $\mathrm{d}, J=3.1 \mathrm{~Hz})$ and the anomeric proton $[\delta 4.84(1 \mathrm{H}, \mathrm{s})]$ was correlated with $\delta_{\mathrm{H}} 4.02(1 \mathrm{H}, \mathrm{d}, J=3.1 \mathrm{~Hz})$ of the Rha I 


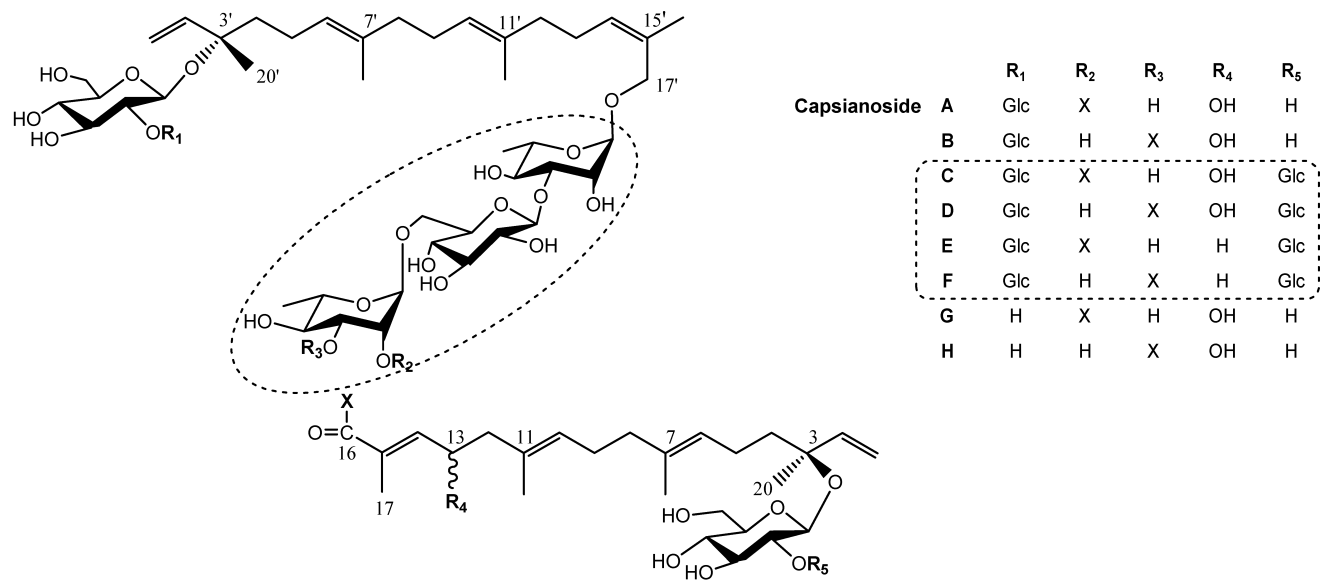
Revised

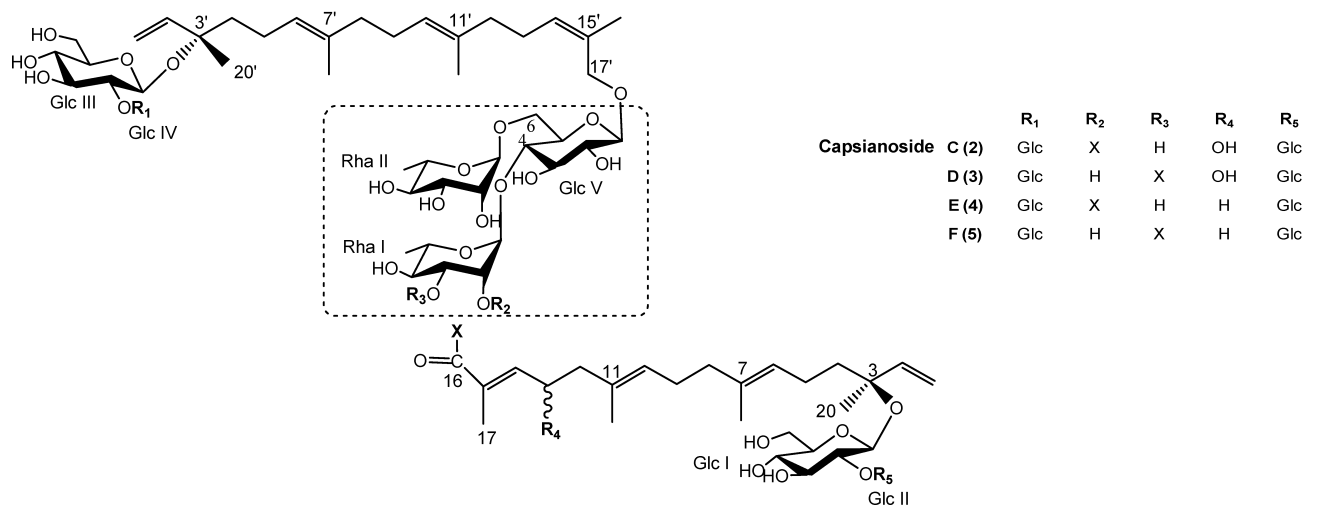

Fig. 3. Structures of $\mathbf{2}-\mathbf{5}$

Table 2. ${ }^{13} \mathrm{C}-\mathrm{NMR}(125 \mathrm{MHz})$ Spectroscopic Data for Aglycone of Compounds $\mathbf{2}-\mathbf{5}$ in $\mathrm{CD}_{3} \mathrm{OD}$

\begin{tabular}{|c|c|c|c|c|c|c|c|c|c|c|c|c|c|c|c|}
\hline Position & 2 & Position & 2 & Position & 3 & Position & 3 & Position & 4 & Position & 4 & Position & 5 & Position & 5 \\
\hline 1 & 116.0 & $1^{\prime}$ & 116.0 & 1 & 116.0 & $1^{\prime}$ & 116.0 & 1 & 116.0 & $1^{\prime}$ & 116.0 & 1 & 116.0 & $1^{\prime}$ & 116.0 \\
\hline 2 & 144.4 & $2^{\prime}$ & 144.4 & 2 & 144.4 & $2^{\prime}$ & 144.4 & 2 & 144.4 & $2^{\prime}$ & 144.4 & 2 & 144.4 & $2^{\prime}$ & 144.4 \\
\hline 3 & 82.1 & $3^{\prime}$ & 82.1 & 3 & 82.1 & $3^{\prime}$ & 82.1 & 3 & 82.1 & $3^{\prime}$ & 82.1 & 3 & 82.0 & $3^{\prime}$ & 82.0 \\
\hline 4 & 43.1 & $4^{\prime}$ & 43.1 & 4 & 43.0 & $4^{\prime}$ & 43.0 & 4 & 43.1 & $4^{\prime}$ & 43.1 & 4 & 43.1 & $4^{\prime}$ & 43.1 \\
\hline 5 & 23.6 & $5^{\prime}$ & 23.6 & 5 & 23.6 & $5^{\prime}$ & 23.6 & 5 & 23.6 & $5^{\prime}$ & 23.6 & 5 & 23.6 & $5^{\prime}$ & 23.6 \\
\hline 6 & 125.9 & $6^{\prime}$ & 125.8 & 6 & 125.9 & $6^{\prime}$ & 125.8 & 6 & 125.9 & $6^{\prime}$ & 125.8 & 6 & 125.8 & $6^{\prime}$ & 125.9 \\
\hline 7 & 136.0 & $7^{\prime}$ & 135.5 & 7 & 135.9 & $7^{\prime}$ & 135.5 & 7 & 136.0 & $7^{\prime}$ & 135.5 & 7 & 135.9 & $7^{\prime}$ & 135.5 \\
\hline 8 & 40.5 & $8^{\prime}$ & 40.8 & 8 & 40.8 & $8^{\prime}$ & 40.9 & 8 & 40.7 & $8^{\prime}$ & 40.8 & 8 & 40.7 & $8^{\prime}$ & 40.8 \\
\hline 9 & 27.7 & $9^{\prime}$ & 27.8 & 9 & 27.7 & $9^{\prime}$ & 27.7 & 9 & 27.7 & $9^{\prime}$ & 27.7 & 9 & 27.6 & $9^{\prime}$ & 27.7 \\
\hline 10 & 129.3 & $10^{\prime}$ & 125.9 & 10 & 129.2 & $10^{\prime}$ & 125.9 & 10 & 126.3 & $10^{\prime}$ & 125.9 & 10 & 126.2 & $10^{\prime}$ & 125.9 \\
\hline 11 & 131.8 & $11^{\prime}$ & 136.1 & 11 & 131.9 & $11^{\prime}$ & 136.0 & 11 & 135.2 & $11^{\prime}$ & 136.1 & 11 & 135.2 & $11^{\prime}$ & 136.0 \\
\hline 12 & 47.9 & $12^{\prime}$ & 40.9 & 12 & 47.9 & $12^{\prime}$ & 40.5 & 12 & 39.3 & $12^{\prime}$ & 40.9 & 12 & 39.3 & $12^{\prime}$ & 40.9 \\
\hline 13 & 68.0 & $13^{\prime}$ & 27.3 & 13 & 68.1 & $13^{\prime}$ & 27.3 & 13 & 28.6 & $13^{\prime}$ & 27.3 & 13 & 28.6 & $13^{\prime}$ & 27.3 \\
\hline 14 & 145.9 & $14^{\prime}$ & 131.3 & 14 & 145.4 & $14^{\prime}$ & 131.2 & 14 & 144.6 & $14^{\prime}$ & 131.3 & 14 & 144.1 & $14^{\prime}$ & 131.2 \\
\hline 15 & 128.9 & $15^{\prime}$ & 132.4 & 15 & 129.0 & $15^{\prime}$ & 132.4 & 15 & 128.6 & $15^{\prime}$ & 132.4 & 15 & 128.8 & $15^{\prime}$ & 132.4 \\
\hline 16 & 169.2 & $16^{\prime}$ & 21.9 & 16 & 169.3 & $16^{\prime}$ & 21.9 & 16 & 169.3 & $16^{\prime}$ & 21.9 & 16 & 169.5 & $16^{\prime}$ & 21.9 \\
\hline 17 & 13.1 & $17^{\prime}$ & 67.7 & 17 & 13.1 & $17^{\prime}$ & 67.9 & 17 & 12.6 & $17^{\prime}$ & 67.8 & 17 & 12.6 & $17^{\prime}$ & 67.9 \\
\hline 18 & 16.8 & $18^{\prime}$ & 16.3 & 18 & 16.7 & $18^{\prime}$ & 16.3 & 18 & 16.3 & $18^{\prime}$ & 16.2 & 18 & 16.3 & $18^{\prime}$ & 16.3 \\
\hline 19 & 16.3 & $19^{\prime}$ & 16.3 & 19 & 16.2 & $19^{\prime}$ & 16.3 & 19 & 16.2 & $19^{\prime}$ & 16.2 & 19 & 16.2 & $19^{\prime}$ & 16.3 \\
\hline 20 & 23.5 & $20^{\prime}$ & 23.5 & 20 & 23.5 & $20^{\prime}$ & 23.5 & 20 & 23.4 & $20^{\prime}$ & 23.4 & 20 & 23.4 & $20^{\prime}$ & 23.4 \\
\hline
\end{tabular}


Table 3. ${ }^{13} \mathrm{C}-\mathrm{NMR}(125 \mathrm{MHz})$ Spectroscopic Data for Sugar Moiety of Compounds $\mathbf{2}-\mathbf{5}$ in $\mathrm{CD}_{3} \mathrm{OD}$

\begin{tabular}{|c|c|c|c|c|c|c|c|c|c|c|c|c|c|c|c|}
\hline Position & 2 & Position & 2 & Position & 3 & Position & 3 & Position & 4 & Position & 4 & Position & 5 & Position & 5 \\
\hline Glc I-1 & 98.4 & Glc V-1 & 102.3 & Glc I-1 & 98.3 & Glc V-1 & 102.3 & Glc I-1 & 98.4 & Glc V-1 & 102.3 & Glc I-1 & 98.3 & Glc V-1 & 102.4 \\
\hline 2 & 83.3 & 2 & 75.4 & 2 & 83.2 & 2 & 75.4 & 2 & 83.3 & 2 & 75.5 & 2 & 83.3 & 2 & 75.5 \\
\hline 3 & 77.7 & 3 & 76.6 & 3 & 77.7 & 3 & 76.8 & 3 & 77.7 & 3 & 76.6 & 3 & 77.7 & 3 & 75.3 \\
\hline 4 & 71.5 & 4 & 78.6 & 4 & 71.5 & 4 & 79.2 & 4 & 71.5 & 4 & 78.6 & 4 & 71.5 & 4 & 79.3 \\
\hline 5 & 77.5 & 5 & 75.4 & 5 & 77.5 & 5 & 75.4 & 5 & 77.5 & 5 & 75.5 & 5 & 77.5 & 5 & 75.3 \\
\hline 6 & 62.8 & 6 & 66.2 & 6 & 62.8 & 6 & 66.9 & 6 & 62.8 & 6 & 66.2 & 6 & 62.8 & 6 & 66.9 \\
\hline Glc II-1 & 105.9 & Rha I-1 & 99.3 & Glc II-1 & 105.9 & Rha I-1 & 102.7 & Glc II-1 & 105.9 & Rha I-1 & 99.4 & Glc II-1 & 105.9 & Rha I-1 & 102.7 \\
\hline 2 & 76.6 & 2 & 75.0 & 2 & 76.6 & 2 & 70.2 & 2 & 76.6 & 2 & 74.7 & 2 & 76.6 & 2 & 70.3 \\
\hline 3 & 78.3 & 3 & 70.4 & 3 & 78.3 & 3 & 75.8 & 3 & 78.3 & 3 & 70.4 & 3 & 78.3 & 3 & 75.5 \\
\hline 4 & 71.7 & 4 & 74.1 & 4 & 71.7 & 4 & 71.7 & 4 & 71.7 & 4 & 74.1 & 4 & 71.7 & 4 & 71.7 \\
\hline 5 & 78.1 & 5 & 70.4 & 5 & 78.1 & 5 & 70.8 & 5 & 78.1 & 5 & 70.5 & 5 & 78.1 & 5 & 70.8 \\
\hline 6 & 62.8 & 6 & 18.2 & 6 & 62.8 & 6 & 18.2 & 6 & 62.8 & 6 & 18.2 & 6 & 62.8 & 6 & 18.2 \\
\hline Glc III-1 & 98.4 & Rha II-1 & 101.1 & Glc III-1 & 98.3 & Rha II-1 & 101.5 & Glc III-1 & 98.4 & Rha II-1 & 101.1 & Glc III-1 & 98.3 & Rha II-1 & 101.5 \\
\hline 2 & 83.3 & 2 & 72.3 & 2 & 83.3 & 2 & 72.2 & 2 & 83.3 & 2 & 72.3 & 2 & 83.3 & 2 & 72.2 \\
\hline 3 & 77.7 & 3 & 72.5 & 3 & 77.7 & 3 & 72.4 & 3 & 77.7 & 3 & 72.5 & 3 & 76.8 & 3 & 72.4 \\
\hline 4 & 71.7 & 4 & 74.4 & 4 & 71.1 & 4 & 74.0 & 4 & 71.7 & 4 & 74.4 & 4 & 71.2 & 4 & 74.0 \\
\hline 5 & 77.5 & 5 & 69.6 & 5 & 77.5 & 5 & 69.8 & 5 & 77.5 & 5 & 69.6 & 5 & 77.5 & 5 & 69.8 \\
\hline 6 & 62.8 & 6 & 18.0 & 6 & 62.8 & 6 & 17.9 & 6 & 62.8 & 6 & 18.0 & 6 & 62.8 & 6 & 17.9 \\
\hline Glc IV-1 & 105.9 & & & Glc IV-1 & 105.8 & & & Glc IV-1 & 105.9 & & & Glc IV-1 & 105.9 & & \\
\hline 2 & 76.6 & & & 2 & 76.6 & & & 2 & 76.6 & & & 2 & 76.6 & & \\
\hline 3 & 78.1 & & & 3 & 78.1 & & & 3 & 78.1 & & & 3 & 78.1 & & \\
\hline 4 & 71.5 & & & 4 & 71.5 & & & 4 & 71.5 & & & 4 & 71.7 & & \\
\hline 5 & 78.3 & & & 5 & 78.3 & & & 5 & 78.3 & & & 5 & 77.7 & & \\
\hline 6 & 62.8 & & & 6 & 62.8 & & & 6 & 62.8 & & & 6 & 62.8 & & \\
\hline
\end{tabular}

Table 4. Distribution of Capsianosides in Previous Study of Capsicum Plants

\begin{tabular}{|c|c|c|c|c|c|c|c|c|}
\hline Capsianoside & A & $\mathrm{B}$ & $\mathrm{C}$ & $\mathrm{D}$ & $\mathrm{E}$ & $\mathrm{F}$ & G & $\mathrm{H}$ \\
\hline C. annuum var. fasciculatum (Yatsubusa) & $\bigcirc$ & $\bigcirc$ & $\bigcirc$ & O & & & & \\
\hline C. annuum var. conoides (Takanotsume) & & & $\bigcirc$ & $\bigcirc$ & & & & \\
\hline C. annuum var. grossum (Shishitougarashi) & $\bigcirc$ & $\bigcirc$ & $\bigcirc$ & O & & & & \\
\hline C. annuum var. grossum (Pimiento) & & & $\bigcirc$ & $\bigcirc$ & $\bigcirc$ & O & & \\
\hline C. annuum var. fasciculatum (Yatsubusa, aerial parts) & $\bigcirc$ & $\bigcirc$ & $\bigcirc$ & $\bigcirc$ & & & O & $\bigcirc$ \\
\hline C. annuum var. conoides (Takanotsume, aerial parts) & $\bigcirc$ & $\bigcirc$ & $\bigcirc$ & $\bigcirc$ & & & $\bigcirc$ & $\bigcirc$ \\
\hline
\end{tabular}

in the TOCSY. The evidence from the ${ }^{13} \mathrm{C}-\mathrm{NMR}$ spectrum of 5 was also consistent with that of the ${ }^{1} \mathrm{H}-\mathrm{NMR}$ spectrum. Hence, the structure of $\mathbf{5}$ could be determined to be $3^{\prime}-O-\beta$-D-glucopyranosyl-( $(1 \rightarrow 2)-\beta$-D-glucopyranosyl $6^{\prime} E, 10^{\prime} E, 14^{\prime} Z-\left(3^{\prime} S\right)-17^{\prime}$-hydroxygeranyllinalool $17^{\prime}-O-[3-O-$ $\beta$-D-glucopyranosyl-(1 $\rightarrow 2)$ - $\beta$-D-glucopyranosyl $6 E, 10 E, 14 Z$ $(3 S)$-geranyllinalool-16-oyl $(16 \rightarrow 3)]-\alpha$-L-rhamnopyranosyl$(1 \rightarrow 4)$-[ $\alpha$-L-rhamnopyranosyl-( $1 \rightarrow 6)]-\beta$-D-glucopyranoside.

Since previous study committed the mistake at the sugar combination owing to ambiguous assignments in the ${ }^{1} \mathrm{H}-{ }^{1} \mathrm{H}$ COSY without HMBC technique, here, we have proposed the corrected structures as shown in Fig. 3 including previous Capsicum investigations.

Capsianosides II, I, A, and D in vitro inhibited angiotensin converting enzyme $3.6 \%$ at $0.77 \mathrm{mg}, 22.1 \%$ at $1.97 \mathrm{mg}$, $31.1 \%$ at $1.15 \mathrm{mg}$ and $32.8 \%$ at $2.47 \mathrm{mg}$, individually. Capsianoside D in vitro inhibited renin $49.7 \%$ at $20 \mathrm{mg} / \mathrm{ml}$ and $23.4 \%$ at $2 \mathrm{mg} / \mathrm{ml}$. So, capsianosides are useful for the improvement and prevention of hypertension. ${ }^{11)}$ These acyclic diterpenes have been revealed rarely in nature. For efficient utilization of natural resources, we plan research of aerial parts and perform various pharmacological tests.

\section{Experimental}

The optical rotations were measured with a JASCO DIP-1000 $(l=0.5)$ automatic digital polarimeter. ${ }^{1} \mathrm{H}$ - and ${ }^{13} \mathrm{C}$-NMR spectra were measured with JEOL- $\alpha-500$ NMR spectrometers, and chemical shifts are given on a $\delta$ (ppm) scale with tetramethylsilane as an internal standard. The HR-ESI-MS were measured with JEOL JMS T-100LP spectrometer. TLC was performed on silica gel plates (Kieselgel $60 \mathrm{~F}_{254}$, Merck) and $\mathrm{RP} \mathrm{C}_{18}$ silica gel plates (Merck). The spots on TLC were visualized by UV light $(254 / 366 \mathrm{~nm})$ and sprayed with $10 \% \mathrm{H}_{2} \mathrm{SO}_{4}$, followed by heating. Column chromatography was carried out on Diaion HP-20 (Mitsubishi Chemical Ind.), MCI, ODS (Wako Pure Chemical Industries, Ltd., Fuji Silysia Chemical, Ltd., Japan), and silica gel 60 (spherical, 40-100 mm, and 230-400 mesh ASTM; crushed, $40-63 \mu \mathrm{m}$, and 230 - 400 mesh ASTM, Kanto Chemical Co. Inc.).

Plant Material The dried fruits of hot red pepper Capsicum annuum L. were purchased in Kumamoto city, Japan.

Extraction and Isolation The dried hot red pepper $(800 \mathrm{~g})$ was extracted successively with $100 \% \mathrm{MeOH}$ (three times). After evaporation of $\mathrm{MeOH}$ in vacuo, residue $(225.77 \mathrm{~g})$ was suspended in water to subjected to Diaion HP-20 using $\mathrm{H}_{2} \mathrm{O}$ and $\mathrm{MeOH}(100 \%)$. The fraction $(23.58 \mathrm{~g})$ eluted with $\mathrm{MeOH}$ was subjected to MCI column chromatography (eluted with $50-100 \% \mathrm{MeOH})$. The fractions eluted with $\mathrm{MeOH} / \mathrm{H}_{2} \mathrm{O}$ were subsequently subjected to silica gel column chromatography $\left(\mathrm{CHCl}_{3} / \mathrm{MeOH} / \mathrm{H}_{2} \mathrm{O}\right.$ solvent system, $8: 2: 0.2-6: 4: 1$ ), and ODS (Chromatorex) column chromatography $\left(\mathrm{MeOH} / \mathrm{H}_{2} \mathrm{O}\right.$ solvent system, $\left.55-85 \% \mathrm{MeOH}\right)$. From the dried hot pepper, capsianosides I' (19.7 mg), II (672.3 mg), III (200.5 mg), C (15.2 mg), D (40.4 mg), E (60.2 mg) and F (56.2 mg) were obtained.

Capsianoside III (1): An amorphous powder, $[\alpha]_{\mathrm{D}}^{25}-28.6^{\circ}(c=0.65$, $\mathrm{MeOH}$ ), HR-ESI-MS [M+Na] ${ }^{+} m / z 1123.5127$ (Calcd for $\mathrm{C}_{50} \mathrm{H}_{84} \mathrm{O}_{26} \mathrm{Na}$, 1123.5149). ${ }^{1} \mathrm{H}-\mathrm{NMR}\left(\mathrm{CD}_{3} \mathrm{OD}\right) \delta: 1.26\left(3 \mathrm{H}, \mathrm{d}, J=6.1 \mathrm{~Hz}, \mathrm{Rha}_{3}-6\right), 1.39$, $1.61 \times 2,1.79$ (each $\left.3 \mathrm{H}, \mathrm{s}, \mathrm{H}_{3}-20, \mathrm{H}_{3}-19, \mathrm{H}_{3}-18, \mathrm{H}_{3}-16\right), 1.60\left(2 \mathrm{H}, \mathrm{m}, \mathrm{H}_{2}-4\right)$, 1.95-2.20 (10H, m, $\left.\mathrm{H}_{2}-5, \mathrm{H}_{2}-8, \mathrm{H}_{2}-9, \mathrm{H}_{2}-12, \mathrm{H}_{2}-13\right), 3.20-4.00(\mathrm{~m}$ sugar), 4.21, 4.30 (each $\left.1 \mathrm{H}, \mathrm{d}, J=11.6 \mathrm{~Hz}, \mathrm{H}_{2}-17\right), 4.35(1 \mathrm{H}, \mathrm{d}, J=7.3 \mathrm{~Hz}$, Glc III H-1), 4.47, 4.56, 4.63 (each 1H, d, $J=7.9$ Hz, Glc I H-1, Glc II H-1, Glc IV H-1), 4.75 (1H, s, Rha H-1), $5.13 \times 2$ (each 1H, m, H-6, H-10), 5.22 $(1 \mathrm{H}$, brd, H-1b), 5.23 (1H, brd, H-1a), 5.39 (1H, t, H-14), 6.13 (1H, dd, 
$J=11.0,18.3 \mathrm{~Hz}, \mathrm{H}-2)$.

Capsianoside C (2): An amorphous powder, $[\alpha]_{\mathrm{D}}^{25}-23.5^{\circ}(c=0.41$, $\mathrm{MeOH}$ ), HR-ESI-MS $m / z 1749.8584[\mathrm{M}+\mathrm{Na}]^{+}$(Calcd for $\mathrm{C}_{82} \mathrm{H}_{134} \mathrm{O}_{38} \mathrm{Na}$, 1749.8451). ${ }^{1} \mathrm{H}-\mathrm{NMR}\left(\mathrm{CD}_{3} \mathrm{OD}\right) \delta: 1.27\left(3 \mathrm{H}, \mathrm{d}, J=6.1 \mathrm{~Hz}, \mathrm{Rha}_{3}-6\right), 1.30$ $\left(3 \mathrm{H}, \mathrm{d}, J=6.1 \mathrm{~Hz}\right.$, Rha $\left.\mathrm{H}_{3}-6\right), 1.39 \times 2,1.61 \times 3,1.66,1.77,1.89$ (each $3 \mathrm{H}, \mathrm{s}$, $\left.\mathrm{H}_{3}-20, \mathrm{H}_{3}-20^{\prime}, \mathrm{H}_{3}-18^{\prime}, \mathrm{H}_{3}-19, \mathrm{H}_{3}-19^{\prime}, \mathrm{H}_{3}-18, \mathrm{H}_{3}-16^{\prime}, \mathrm{H}_{3}-17\right), 1.95-2.20$ $\left(10 \mathrm{H}, \mathrm{m}, \mathrm{H}_{2}-5, \mathrm{H}_{2}-8, \mathrm{H}_{2}-9, \mathrm{H}_{2}-12, \mathrm{H}_{2}-13\right), 3.20-4.00$ (m, sugar), $3.89(1 \mathrm{H}$, dd, $J=3.1,7.8 \mathrm{~Hz}$, Rha I H-3), 4.12, 4.33 (each $1 \mathrm{H}, \mathrm{d}, J=11.6 \mathrm{~Hz}, \mathrm{H}-17^{\prime} \mathrm{b}$, H-17'a), $4.21(1 \mathrm{H}, \mathrm{d}, J=7.9 \mathrm{~Hz}$, Glc V H-1), $4.47 \times 2,4.56 \times 2($ each $1 \mathrm{H}, \mathrm{d}$ $J=7.9 \mathrm{~Hz}$, Glc I H-1, Glc II H-1, Glc III H-1, Glc IV H-1), 4.53 (1H, m, H13), $4.81(1 \mathrm{H}, \mathrm{s}$, Rha II H-1), $4.90(1 \mathrm{H}, \mathrm{s}$, Rha I H-1 $), 4.98(1 \mathrm{H}, \mathrm{d}$, $J=3.1 \mathrm{~Hz}$, Rha I H-2), $5.12 \times 3$ (each 1H, m, H-6, H-6', H-10'), $5.21(1 \mathrm{H}, \mathrm{m}$, $\mathrm{H}-10$ ), $5.22 \times 2$ (each $1 \mathrm{H}, \mathrm{d}, J=11.6 \mathrm{~Hz}, \mathrm{H}-1 \mathrm{~b}, \mathrm{H}-1^{\prime} \mathrm{b}$ ), $5.23 \times 2$ (each $1 \mathrm{H}, \mathrm{d}$, $\left.J=17.1 \mathrm{~Hz}, \mathrm{H}-1 \mathrm{a}, \mathrm{H}-1^{\prime} \mathrm{a}\right), 5.40$ (1H, t, H-14'), 6.12 (each $1 \mathrm{H}, \mathrm{dd}, J=10.7$, $\left.18.0 \mathrm{~Hz}, \mathrm{H}-2, \mathrm{H}-2^{\prime}\right), 6.71(1 \mathrm{H}, \mathrm{dd}, J=1.2,8.6 \mathrm{~Hz}, \mathrm{H}-14)$.

Capsianoside D (3): An amorphous powder, $[\alpha]_{\mathrm{D}}^{25}-27.4^{\circ}(c=0.19$, $\mathrm{MeOH}$ ), HR-ESI-MS $m / z$ 1749.8251 [M+Na] ${ }^{+}\left(\right.$Calcd for $\mathrm{C}_{82} \mathrm{H}_{134} \mathrm{O}_{38} \mathrm{Na}$, 1749.8451). ${ }^{1} \mathrm{H}-\mathrm{NMR}\left(\mathrm{CD}_{3} \mathrm{OD}\right) \delta: 1.27\left(3 \mathrm{H}, \mathrm{d}, J=6.1 \mathrm{~Hz}\right.$, Rha $\left.\mathrm{H}_{3}-6\right), 1.30$ $\left(3 \mathrm{H}, \mathrm{d}, J=6.1 \mathrm{~Hz}\right.$, Rha $\left.\mathrm{H}_{3}-6\right), 1.39 \times 2,1.60 \times 3,1.77,1.89,1.99$ (each $3 \mathrm{H}, \mathrm{s}$, $\left.\mathrm{H}_{3}-20, \mathrm{H}_{3}-20^{\prime}, \mathrm{H}_{3}-18^{\prime}, \mathrm{H}_{3}-19, \mathrm{H}_{3}-19^{\prime}, \mathrm{H}_{3}-18, \mathrm{H}_{3}-16^{\prime}, \mathrm{H}_{3}-17\right), 1.95-2.20$ (10H, m, $\mathrm{H}_{2}-5, \mathrm{H}_{2}-8, \mathrm{H}_{2}-9, \mathrm{H}_{2}-12, \mathrm{H}_{2}-13$ ), $3.20-4.00$ (m, sugar), 4.15, 4.32 (each $\left.1 \mathrm{H}, \mathrm{d}, J=11.6 \mathrm{~Hz}, \mathrm{H}-17^{\prime} \mathrm{b}, \mathrm{H}-17^{\prime} \mathrm{a}\right), 4.03(1 \mathrm{H}, \mathrm{d}, J=3.1 \mathrm{~Hz}$, Rha I H2), $4.23(1 \mathrm{H}, \mathrm{d}, J=7.9 \mathrm{~Hz}$, Glc V H-1), $4.47 \times 2,4.56 \times 2($ each $1 \mathrm{H}, \mathrm{d}$, $J=7.3 \mathrm{~Hz}$, Glc I H-1, Glc III H-1, Glc II H-1, Glc IV H-1), 4.53 (1H, m, H13), $4.71(1 \mathrm{H}, \mathrm{s}$, Rha II H-1), $4.84(1 \mathrm{H}, \mathrm{s}$, Rha I H-1), $4.99(1 \mathrm{H}, \mathrm{d}, J=3.1$, $9.8 \mathrm{~Hz}$, Rha I H-3), $5.12 \times 3$ (each 1H, m, H-6, H-6', H-10'), $5.21(1 \mathrm{H}, \mathrm{m}, \mathrm{H}-$ 10), $5.22 \times 2\left(\right.$ each $\left.1 \mathrm{H}, \mathrm{d}, J=11.6 \mathrm{~Hz}, \mathrm{H}-1 \mathrm{~b}, \mathrm{H}-1^{\prime} \mathrm{b}\right), 5.23 \times 2($ each $1 \mathrm{H}, \mathrm{d}$, $\left.J=17.1 \mathrm{~Hz}, \mathrm{H}-1 \mathrm{a}, \mathrm{H}-1^{\prime} \mathrm{a}\right), 5.40\left(1 \mathrm{H}, \mathrm{t}, \mathrm{H}-14^{\prime}\right), 6.12 \times 2$ (each $1 \mathrm{H}, \mathrm{dd}$, $\left.J=10.7,18.0 \mathrm{~Hz}, \mathrm{H}-2, \mathrm{H}-2^{\prime}\right), 6.74(1 \mathrm{H}, \mathrm{dd}, J=1.2,8.6 \mathrm{~Hz}, \mathrm{H}-14)$

Capsianoside E (4): An amorphous powder, $[\alpha]_{\mathrm{D}}^{25}-33.4^{\circ}(c=0.23$, $\mathrm{MeOH}$ ), HR-ESI-MS $m / z 1733.8426[\mathrm{M}+\mathrm{Na}]^{+}\left(\right.$Calcd for $\mathrm{C}_{82} \mathrm{H}_{134} \mathrm{O}_{37} \mathrm{Na}$, 1733.8502). ${ }^{1} \mathrm{H}-\mathrm{NMR}\left(\mathrm{CD}_{3} \mathrm{OD}\right) \delta: 1.27\left(3 \mathrm{H}, \mathrm{d}, J=6.1 \mathrm{~Hz}\right.$, Rha $\left.\mathrm{H}_{3}-6\right), 1.27$ $\left(3 \mathrm{H}, \mathrm{d}, J=6.1 \mathrm{~Hz}, \mathrm{Rha}_{3}-6\right), 1.39 \times 2,1.61 \times 3,1.63,1.77,1.86$ (each $3 \mathrm{H}, \mathrm{s}$, $\left.\mathrm{H}_{3}-20, \mathrm{H}_{3}-20^{\prime}, \mathrm{H}_{3}-18^{\prime}, \mathrm{H}_{3}-19, \mathrm{H}_{3}-19^{\prime}, \mathrm{H}_{3}-18, \mathrm{H}_{3}-16^{\prime}, \mathrm{H}_{3}-17\right), 1.95-2.20$ $\left(10 \mathrm{H}, \mathrm{m}, \mathrm{H}_{2}-5, \mathrm{H}_{2}-8, \mathrm{H}_{2}-9, \mathrm{H}_{2}-12, \mathrm{H}_{2}-13\right), 3.20-4.00$ (m, sugar), $3.88(1 \mathrm{H}$, dd, $J=3.1,9.2 \mathrm{~Hz}$, Rha I H-3), 4.13, 4.33 (each $1 \mathrm{H}, \mathrm{d}, J=11.6 \mathrm{~Hz}, \mathrm{H}-17^{\prime} \mathrm{b}$, $\left.\mathrm{H}-17^{\prime} \mathrm{a}\right), 4.21(1 \mathrm{H}, \mathrm{d}, J=7.9 \mathrm{~Hz}, \mathrm{Glc} \mathrm{V} \mathrm{H}-1), 4.47 \times 2($ each $1 \mathrm{H}, \mathrm{d}, J=7.3 \mathrm{~Hz}$, Glc I H-1, Glc III H-1), $4.56 \times 2$ (each $1 \mathrm{H}, \mathrm{d}, J=7.9 \mathrm{~Hz}$, Glc II H-1, Glc IV $\mathrm{H}-1), 4.81(1 \mathrm{H}, \mathrm{s}$, Rha II H-1), $4.90(1 \mathrm{H}, \mathrm{s}$, Rha I H-1), $4.97(1 \mathrm{H}, \mathrm{d}$, $J=3.7 \mathrm{~Hz}$, Rha I H-2), $5.13 \times 4$ (each $1 \mathrm{H}, \mathrm{m}, \mathrm{H}-6, \mathrm{H}-6^{\prime}, \mathrm{H}-10, \mathrm{H}-10^{\prime}$ ), $5.22 \times 2\left(\right.$ each $\left.1 \mathrm{H}, \mathrm{d}, J=11.0 \mathrm{~Hz}, \mathrm{H}-1 \mathrm{~b}, \mathrm{H}-1^{\prime} \mathrm{b}\right), 5.23 \times 2$ (each $1 \mathrm{H}, \mathrm{d}$ $\left.J=16.5 \mathrm{~Hz}, \mathrm{H}-1 \mathrm{a}, \mathrm{H}-1^{\prime} \mathrm{a}\right), 5.40\left(1 \mathrm{H}, \mathrm{t}, \mathrm{H}-14^{\prime}\right), 6.12 \times 2$ (each $1 \mathrm{H}, \mathrm{dd}$, $\left.J=10.7,18.0 \mathrm{~Hz}, \mathrm{H}-2, \mathrm{H}-2^{\prime}\right), 6.85(1 \mathrm{H}, \mathrm{t}, J=7.3 \mathrm{~Hz}, \mathrm{H}-14)$.
Capsianoside F (5): An amorphous powder, $[\alpha]_{\mathrm{D}}^{25}-33.2^{\circ}(c=0.22$, $\mathrm{MeOH}$ ), HR-ESI-MS $m / z$ 1733.8427 $[\mathrm{M}+\mathrm{Na}]^{+}\left(\mathrm{Calcd}\right.$ for $\mathrm{C}_{82} \mathrm{H}_{134} \mathrm{O}_{37} \mathrm{Na}$, 1733.8502). ${ }^{1} \mathrm{H}-\mathrm{NMR}\left(\mathrm{CD}_{3} \mathrm{OD}\right) \delta: 1.27\left(3 \mathrm{H}, \mathrm{d}, J=6.1 \mathrm{~Hz}\right.$, Rha $\left.\mathrm{H}_{3}-6\right), 1.30$ $\left(3 \mathrm{H}, \mathrm{d}, J=6.1 \mathrm{~Hz}\right.$, Rha $\left.\mathrm{H}_{3}-6\right), 1.39 \times 2,1.61 \times 3,1.63,1.78,1.87$ (each $3 \mathrm{H}, \mathrm{s}$, $\left.\mathrm{H}_{3}-20, \mathrm{H}_{3}-20^{\prime}, \mathrm{H}_{3}-18^{\prime}, \mathrm{H}_{3}-19, \mathrm{H}_{3}-19^{\prime}, \mathrm{H}_{3}-18, \mathrm{H}_{3}-16^{\prime}, \mathrm{H}_{3}-17\right), 1.95-2.20$ ( $\left.10 \mathrm{H}, \mathrm{m}, \mathrm{H}_{2}-5, \mathrm{H}_{2}-8, \mathrm{H}_{2}-9, \mathrm{H}_{2}-12, \mathrm{H}_{2}-13\right), 3.20-4.00$ (m, sugar), 4.16, 4.31 (each $\left.1 \mathrm{H}, \mathrm{d}, J=11.6 \mathrm{~Hz}, \mathrm{H}-17^{\prime} \mathrm{b}, \mathrm{H}-17^{\prime} \mathrm{a}\right), 4.02(1 \mathrm{H}, \mathrm{d}, J=3.1 \mathrm{~Hz}$, Rha I H2), $4.23(1 \mathrm{H}, \mathrm{d}, J=7.9 \mathrm{~Hz}, \mathrm{Glc} \mathrm{V} \mathrm{H}-1), 4.48 \times 2$ (each $1 \mathrm{H}, \mathrm{d}, J=7.3 \mathrm{~Hz}, \mathrm{Glc} \mathrm{I}$ H-1, Glc III H-1), $4.56 \times 2$ (each $1 \mathrm{H}, \mathrm{d}, J=7.9 \mathrm{~Hz}$, Glc II H-1, Glc IV H-1), $4.71(1 \mathrm{H}, \mathrm{s}$, Rha II H-1) , $4.84(1 \mathrm{H}$, s, Rha I H-1), $4.98(1 \mathrm{H}$, dd, $J=3.1$, $9.8 \mathrm{~Hz}$, Rha I H-3), $5.13 \times 4$ (each $\left.1 \mathrm{H}, \mathrm{m}, \mathrm{H}-6, \mathrm{H}-6^{\prime}, \mathrm{H}-10, \mathrm{H}-10^{\prime}\right), 5.22 \times 2$ (each $1 \mathrm{H}, \mathrm{d}, J=11.0 \mathrm{~Hz}, \mathrm{H}-1 \mathrm{~b}, \mathrm{H}-1^{\prime} \mathrm{b}$ ), $5.22 \times 2$ (each $1 \mathrm{H}, \mathrm{d}, J=18.3 \mathrm{~Hz}, \mathrm{H}-$ 1a, $\left.\mathrm{H}^{\prime} \mathrm{1}^{\prime} \mathrm{a}\right), 5.40\left(1 \mathrm{H}, \mathrm{t}, \mathrm{H}-14^{\prime}\right), 6.11 \times 2($ each $1 \mathrm{H}, \mathrm{dd}, J=11.0,17.7 \mathrm{~Hz}, \mathrm{H}-2$, $\left.\mathrm{H}-2^{\prime}\right), 6.89(1 \mathrm{H}, \mathrm{t}, J=7.3 \mathrm{~Hz}, \mathrm{H}-14)$.

Acid Hydrolysis of 1,2 and 4 with $1 \mathrm{~N}$ HCl- $\mathrm{H}_{2} \mathrm{O}$ A solution of 1 $(9.9 \mathrm{mg}), \mathbf{2}(2.1 \mathrm{mg})$ and $\mathbf{4}(2.1 \mathrm{mg})$ in $1 \mathrm{~N} \mathrm{HCl}-\mathrm{H}_{2} \mathrm{O}$ were heated under reflux for $2 \mathrm{~h}$. The reaction mixture eluted with $\mathrm{H}_{2} \mathrm{O}$ and $\mathrm{MeOH}$ successively was subjected to Amberlite IRA-400. The D-glucose and L-rhamnose in the aqueous layer were detected on TLC $\left(\mathrm{CHCl}_{3}: \mathrm{MeOH}\right.$ : acetone: $\mathrm{H}_{2} \mathrm{O}=$ $3: 3: 3: 1$ ) by comparison of $R f$ value with those of an authentic sample.

\section{References}

1) Kim N. S., Park K. R., Park I. S., Cho Y. J., Bae Y. M., Biosens. Bioelectron., 20, 2283-2291 (2005).

2) Cheigh H. S., Park K. Y., Crit. Rev. Food Sci. Nutr., 34, 175-203 (1994).

3) Thomas B. V., Schreiber A. A., Weisskopf C. P., J. Agric. Food Chem., 46, 2655-2663 (1988)

4) Maria I., Virginia L., Simona D. M., Franco Z., Magdalena B. M., Antonio M., Eduardo M., J. Agric. Food Chem., 49, 2022-2029 (2001).

5) Osuna-Garcia J. A., Wall M. M., Waddell C. A., J. Agric. Food Chem., 46, 5093-5096 (1988)

6) Lee Y., Howard L. R., Villalon B., J. Food Sci., 60, 473-476 (1995).

7) Yahara S., Izumitani Y., Nohara T., Tetrahedron Lett., 29, 1943-1946 (1988).

8) Izumitani Y., Yahara S., Nohara T., Chem. Pharm. Bull., 38, 12991307 (1990).

9) Yahara S., Kobayashi N., Izumitani Y., Nohara T., Chem. Pharm. Bull., 39, 3258-3260 (1991).

10) Lee J. H., Kiyota N., Ikeda T., Nohara T., Chem. Pharm. Bull., 54, 1365-1369 (2006)

11) Yahara S., Nohara T., Irino N., Okuda H., Izumitani Y., Jpn. Kokai Tokkyo Koho, JP02138289 (1990). 